\title{
Evaluation of Linkage of Markers on Chromosome 6p With Schizophrenia in Taiwanese Families
}

\author{
Hai-Gwo Hwu, ${ }^{1 *}$ Ming-Wei Lin, ${ }^{1}$ Ping-Chuan Lee, ${ }^{1}$ Sandy F-C Lee, ${ }^{2}$ Wen-Chen Ou-Yang, ${ }^{2}$ and \\ Chih-Min Liu ${ }^{1}$ \\ ${ }^{1}$ Department of Psychiatry, College of Medicine, National Taiwan University, Taipei, Taiwan \\ ${ }^{2}$ Taoyuan Psychiatric Center, Taoyuan, Taiwan
}

\begin{abstract}
Previous studies have indicated possible linkage of schizophrenia with chromosome 6p21-24. In an attempt to replicate these findings, we studied the linkage of schizophrenia with nine markers on chromosome 6p21-24 in 39 Taiwanese schizophrenic nuclear families with at least two affected siblings. Two diagnostic models (narrow: Diagnostic and Statistical Manual of Mental Disorders-IV schizophrenia only; and broad: including schizophrenia, schizoaffective, and other nonaffective psychotic disorders) were used to define the disease phenotypes. With the broad and narrow diagnostic models, the marker D6S296 produced maximum two-point lod scores of $1.46(\theta=0.2)$ and 1.35 $(\theta=0.2)$, respectively, in the recessive inheritance model. Assuming locus heterogeneity, a multipoint lod score of 0.85 was obtained between markers D6S296 and D6S277 under the narrow/recessive model. Maximum nonparametric lod scores of $1.25(p=$ $0.09)$ and $1.36(p=0.08)$ were observed, but still not statistically significant, at D6S296 in the narrow and broad diagnostic models, respectively. Both two-point analysis of the dominant model (lod score 0.85 ) and nonparametric analysis (lod score 1.25) showed a mild peak lod score appeared at marker D6S 285 as well. The results add some support to the suggestive linkage of schizophrenia with markers in the regions of chromosome $6 \mathrm{p} 22$ and $6 \mathrm{p} 24$ in an ethni-
\end{abstract}

Contract grant sponsor: National Science Council, Taiwan Contract grant numbers: NSC83-0412-B-170-M02, 82-0412-B 002-152-M02, 81-0412-B-002-53; 80-0412-B-002-37, 79-0412-B002-128; Contract grant sponsor: National Health Research Institute, Department of Health, Taiwan; Contract grant number: DOH83, 84, 85, 86, 87, 88-HR-306.

*Correspondence to: Hai-Gwo Hwu, M.D. Department of Psychiatry, National Taiwan University Hospital, No.7 Chung-shan South Road, Taipei, Taiwan 100.

Received 20 January 1999; Accepted 29 July 1999 cally distinct Taiwanese sample. Am. J. Med. Genet. (Neuropsychiatr. Genet.) 96:74-78, 2000. $\odot 2000$ Wiley-Liss, Inc.

KEY WORDS: genotyping; linkage; chromosome 6p; schizophrenia

\section{INTRODUCTION}

A genetic component in the etiology of schizophrenia has been emphasized based on family, twin, and adoption studies [Cloninger, 1988; Gottesman and Shields, 1982]. The mode of inheritance is not known, however, because segregation analyses have revealed contradictory results [Kendler and Diehl, 1993; Risch and Baron, 1984; Tsuang et al., 1982]. Linkage analysis using highly polymorphic markers is an important strategy in searching for the location of potential vulnerability gene(s) of schizophrenia.

A number of studies have found reproducible evidence of such linkage [d'Amato et al., 1992; Kendler et al., 1996; Moises et al., 1995; Pulver et al., 1994; Schwab et al., 1995; Straub et al., 1995; Vallada et al., 1995; Wang et al., 1995]. The initial findings of linkage of schizophrenia with chromosome $6 \mathrm{p}$, as reported by Wang et al. [1995], Straub et al. [1995], Schwab et al. [1995], Antonarakis et al. [1995], and Moises et al. [1995], included a wide range of genome markers from 6p24 (F13A1) to 6p21.2 (D6S282). Chromosome 6P markers were further found to have modest linkage with schizophrenia [Maziade et al., 1997; Schizophrenia Linkage Collaborative Group, 1996]. In a metaanalysis of nine linkage studies comprising 11 chromosome 6P markers, from the most proximal (D6S470) to the most distal (D6S291), Turecki et al. [1997] found markers D6S274 and D6S285, which are $2 \mathrm{cM}$ apart on the genome map, had the most strongly significant pooled $p$-values.

Some other studies [Daniels et al., 1997; Garner et al., 1996; Gurling et al., 1995; Mowry et al., 1995; Riley et al., 1996] could not confirm these findings. Recent reports using whole genome scans [Faraone et al., 
1998; Kaufmann et al., 1998; Levinson et al., 1998] also showed negative results of linkage of schizophrenia with chromosome $6 \mathrm{p}$ markers.

Previous studies suggested that regions of chromosome 6p markers D6S296, D6S285, and D6S291 may be linked with schizophrenia. The samples of these previous studies were of Caucasian populations or of mixed ethnic origins. It is important to investigate whether these findings can be replicated in a distinct ethnic group. Therefore, we recruited the families of Taiwanese schizophrenic probands with at least two affected siblings and sought to confirm these findings.

\section{MATERIALS AND METHODS Subjects}

Schizophrenic probands who had at least two affected sibling(s) were identified from the psychiatric service settings of the Department of Psychiatry, National Taiwan University and the University Affiliated Taoyuan Psychiatric Center. Both hospitals are located in northern Taiwan and serve as referral centers for patients from the northern region of Taiwan. All members of the immediate family including parents and unaffected siblings were also recruited. The data collection was initiated after informed consent was obtained from the identified study subjects and their families. Psychiatric diagnoses were made according to the Psychiatric Diagnostic Assessment Schedule [Hwu et al., 1987, 1991]. The diagnostic interview was performed by the senior author (Hwu). The clinical medical chart records also were used as supplementary data for the final diagnostic ascertainment, according to the diagnostic criteria of the Diagnostic and Statistical Manual of Mental Disorders (DSM-IV) [American Psychiatric Association, 1994] for definition of psychiatric disorders.

\section{Genotyping}

Genomic DNA was isolated from lymphocytes using a modified salting-out method [Lahiri et al., 1993]. Nine highly polymorphic microsatellite markers from the Genethon linkage map [Dib et al., 1996] were used (Table I). Three markers around D6S296 (mean distance of $2.3 \mathrm{cM}$ ), and four markers around D6S285 (mean distance of $1.9 \mathrm{cM}$ ) were used for the study. Two other markers were also used: D6S291, with a distance of $18.2 \mathrm{cM}$ from D6S285, and D6S461, which is located between D6S285 and D6S291 and is $8.1 \mathrm{cM}$ from D6S285.

These nine microsatellite markers were genotyped by means of polymerase polymorphism chain reaction (PCR) techniques [Saiki et al., 1985]. For all reactions, $20 \mathrm{ng}$ of genomic DNA was used as the template. Fluorescent $5^{\prime}$ labeled primers were used for amplification of these markers. The allele types of these markers were determined by analysis with Genescan ${ }^{\mathrm{TM}}$ and Genotyper $^{\mathrm{TM}}$ software by comparison of the fragment sizes with an internal standard in an ABI prism 310 Genetic Analyzer (Perkin-Elmer, U.S.A.). Genotypes were read independently by two individuals blind to the clinical status of the subjects.

\section{Statistical Analyses}

Two diagnostic (narrow and broad) phenotypes were used to define the disease phenotype. The narrow phenotype included DSM-IV schizophrenia only. The broad phenotype included schizophrenia, schizoaffective disorders, and other nonaffective psychotic disorders. Two-point linkage analysis was performed with the MLINK program of LINKAGE (FASTLINK v 3.0) [Cottingham et al, 1983; Lathrop et al, 1984]. Multipoint lod score analyses and nonparametric linkage analyses were performed on the GENEHUNTER (Version 1.1) program [Kruglyak et al., 1996]. Both parametric and nonparametric linkage analyses were performed. In the parametric analyses the parameters of genetic models used for linkage analyses were as follows. Allelic frequencies were calculated from 69 unrelated individuals in the pedigrees. The disease gene frequencies $(\%)$ in the dominant and recessive models were 0.005 and 0.10 , respectively. In both the narrow/ dominant model and the narrow/recessive model, the penetrance was 0.5 and the probability of phenocopy was 0.005 . The penetrance and the probability of phenocopy were 0.7 and 0.01 , respectively, in both the broad/dominant and the broad/recessive model.

\section{RESULTS}

Thirty-nine schizophrenic families with at least two affected siblings were recruited in this study. Of these, 67 parents available for study; five (7.5\%, all females) in five separate families were schizophrenic. Another one (female) had nonaffective psychotic disorder. Eighty-one (68.1\%) (51 male, 30 female) of the 119 sib-

TABLE I. Summary of Characteristics and Distances of Microsatellite Markers Used in this Study

\begin{tabular}{lclccr}
\hline $\begin{array}{l}\text { Distance in } \\
\text { linkage } \\
\text { analysis (cM) }\end{array}$ & $\begin{array}{c}\text { Microsatellite } \\
\text { markers }\end{array}$ & $\begin{array}{c}\text { Chromosome } \\
\text { region }\end{array}$ & $\begin{array}{c}\text { Allele } \\
\text { type }\end{array}$ & Heterzygosity & $\begin{array}{c}\text { Size } \\
\text { range (bp) }\end{array}$ \\
\hline 0.00 & D6S296 & $6 \mathrm{p} 24.2-\mathrm{p} 23$ & 13 & 0.78 & $260-300$ \\
1.01 & D6S277 & $6 \mathrm{p} 24.2-\mathrm{p} 23$ & 10 & 0.79 & $98-120$ \\
4.64 & D6S470 & $6 \mathrm{p} 24.2-\mathrm{p} 23$ & 7 & 0.80 & $120-134$ \\
18.49 & D6S289 & $6 \mathrm{p} 23$ & 7 & 0.79 & $215-227$ \\
19.50 & D6S260 & $6 \mathrm{p} 23$ & 11 & 0.84 & $159-179$ \\
22.38 & D6S274 & $6 \mathrm{p} 23$ & 9 & 0.81 & $170-186$ \\
24.11 & D6S285 & $6 \mathrm{p} 22.3-\mathrm{p} 22.2$ & 6 & 0.75 & $207-221$ \\
32.24 & D6S461 & $6 \mathrm{p} 22-\mathrm{p} 21$ & 9 & 0.72 & $246-268$ \\
42.28 & D6S291 & $6 \mathrm{p} 21.3-\mathrm{p} 21.2$ & 7 & 0.70 & $198-210$ \\
\hline
\end{tabular}


lings available (72 male, 47 female) were affected with either schizophrenia or schizoaffective disorder. The mean age of onset of the initial nonspecific clinical symptoms was $21.7( \pm 7.0)$ years, while the mean age of onset of definite psychotic symptoms (delusion, hallucination, thought disorder, or bizarre behavior) was $22.5( \pm 6.8)$ years. Seventy-seven siblings $(65.5 \%)$ (48 male, 29 female) were schizophrenic, whereas three (2.5\%) (two males, one female) had schizoaffective disorder. Among the siblings of these 39 families, there were three affected triplets and 36 affected pairs.

Table II shows the results of two-point linkage analyses, assuming the existence of heterogeneity, under narrow and broad phenotype models. In the recessive inheritance model, D6S296 had the highest lod score of the nine markers, regardless of whether the broad or narrow definition was used. In the dominant model, the lod scores showed small peaks at D6S285 in both the narrow and broad phenotype analyses.

Table III shows the results of multipoint linkage analysis under the assumption of genetic heterogeneity, as well as the results of nonparametric analysis. In nonparametric analysis there were two high lod score peaks of $1.25(p=0.09)$ and $1.26(p=0.09)$ at D6S296 and D6S285, respectively, in the narrow disease phenotype model. Under the broad disease phenotype model there were also two high lod score peaks of 1.36 $(p=0.08)$ and $1.14(p=0.12)$ at D6S296 and D6S285, respectively. There were small peaks of lod scores of $0.74(p=0.22)$ and $0.76(p=0.22)$ at D6S291 in both the narrow and broad disease phenotype models.

In the recessive transmission model, the lod scores at D6S296 in the narrow and broad disease phenotype models were 0.84 and 0.80 , respectively. A mild peak of lod score (0.78) was also found at D6S291 in the dominant inheritance/broad disease phenotype model.

\section{DISCUSSION}

The results of this study, using a distinct ethnic group of Taiwanese families, were compatible with the results reported by some authors with study populations of different ethnic origin [Antonarakis et al, 1995; Moises et al., 1995; Schwab et al., 1995; Straub et al., 1995; Wang et al., 1995].

Although the lod scores revealed in this study were not very high, these results do provide additional support for the linkage of schizophrenia with two or three regions of chromosome $6 \mathrm{p}$ (Tables II and III). Two things support this assertion. First, the results obtained by nonparametric analysis are not in conflict with these parametric analyses performed under dominant and recessive models inheritance models. These were observed in the analyses of markers of D6S296, D6S285 (D6S274), and D6S291 (Tables II and III).

Second, there was a gradual change of lod score among nearby markers separated by short distances. The lod scores of D6S296, D6S277, and D6S470 were $1.25,1.15$ and 1.23 , respectively, in nonparametric analyses. The lod score of D6S289, which is located far from D6S470, was only 0.49. In parametric analyses, under the recessive model, the lod scores of D6S296 were 1.35 and 1.46 (both at $\theta=0.2$ ) in narrow and broad models, respectively. When recessive inheritance was assumed, the lod scores of D6S277 were $0.45(=0.2)$ in the narrow model and $0.31(\theta=0.3)$ in the broad model. D6S285 and D6S291 also had high lod scores in both the recessive/narrow and recessive/broad models.

Finally, when genetic heterogeneity was assumed, D6S296 had the strongest evidence of linkage with schizophrenia under the recessive model, whereas D6S285 (D6S274) and D6S291 showed the strongest evidence of linkage under the dominant model. These data are compatible with the hypothesis of genetic heterogeneity of schizophrenia [Gottesman and Shields, 1982; Kendler and Diehl, 1993; Tsuang et al., 1982] and suggest the need for further study of this hypothesis.

This study included 39 nuclear families composed of 186 subjects as the study samples. Because of its small size, this statistical power of this study may not have been sufficient to detect linkage. Therefore, we implemented a simulation test to evaluate the power to detect linkage in this sample. Under the assumption of heterogeneity with 40 and $70 \%$ of the families linked, the powers to detect a lod score $\geq 3$ in the recessive model were 0.32 and 0.62 , respectively. Because of the limited statistical power, our results cannot be considered conclusive; however, they are still of value in providing further suggestive evidence of linkage of schizophrenia with various regions of chromosome $6 \mathrm{p}$. Further studies, using a larger number of study families of a distinct ethnic group, of the linkage of chromosome $6 p$ markers with schizophrenia are encouraged.

TABLE II. Two-Point Linkage Results of Schizophrenia for Markers on Chromosome 6p With the Narrow and Broad Disease Phenotypes for the Taiwanese Pedigrees $(N=39)$

\begin{tabular}{|c|c|c|c|c|c|c|c|c|c|c|c|c|}
\hline \multirow[b]{3}{*}{ Marker } & \multicolumn{6}{|c|}{ Narrow model } & \multicolumn{6}{|c|}{ Broad model } \\
\hline & \multicolumn{3}{|c|}{ Dominant A- lod score } & \multicolumn{3}{|c|}{ Recessive A- lod score } & \multicolumn{3}{|c|}{ Dominant A- lod score } & \multicolumn{3}{|c|}{ Recessive A- lod score } \\
\hline & $\theta$ & A-lod & $\alpha$ & $\theta$ & A-lod & $\alpha$ & $\theta$ & A-lod & $\alpha$ & $\theta$ & A-lod & $\alpha$ \\
\hline D6S296 & 0.3 & 0.19 & 1.0 & 0.2 & 1.35 & 1.0 & 0.3 & 0.12 & 0.95 & 0.2 & 1.46 & 1.0 \\
\hline D6S277 & 0 & 0 & 0 & 0.2 & 0.45 & 0.75 & 0 & 0 & 0 & 0.3 & 0.31 & 1.0 \\
\hline D6S470 & 0.4 & 0.03 & 1.0 & 0 & 0.49 & 0.25 & 0 & 0 & 0 & 0 & 0.21 & 0.15 \\
\hline D6S289 & 0.3 & 0.14 & 1.0 & 0.4 & 0.03 & 1.0 & 0.3 & 0.09 & 0.9 & 0 & 0 & 0 \\
\hline D6S260 & 0.3 & 0.14 & 1.0 & 0.4 & 0.03 & 1.0 & 0.4 & 0.06 & 1.0 & 0 & 0 & 0 \\
\hline D6S274 & 0.2 & 0.16 & 0.7 & 0.4 & 0.03 & 1.0 & 0.3 & 0.05 & 0.7 & 0 & 0 & 0 \\
\hline D6S285 & 0.1 & 0.85 & 1.0 & 0.2 & 0.32 & 0.9 & 0.1 & 0.72 & 0.85 & 0.2 & 0.32 & 0.9 \\
\hline D6S461 & 0 & 0 & 0 & 0 & 0.06 & 0.1 & 0 & 0 & 0 & 0 & 0 & 0 \\
\hline D6S291 & 0.2 & 0.18 & 0.65 & 0.4 & 0.02 & 1.0 & 0.2 & 0.57 & 0.95 & 0.4 & 0.01 & 1.0 \\
\hline
\end{tabular}


TABLE III. Lod Scores of Parametric Multipoint Linkage Analyses Under Assumption of Genetic Heterogeneity in Narrow and Broad Disease Phenotypes for the Taiwanese Pedigrees $(N=39)$

\begin{tabular}{|c|c|c|c|c|c|c|c|c|c|c|c|c|}
\hline & \multicolumn{6}{|c|}{ Narrow model } & \multicolumn{6}{|c|}{ Broad model } \\
\hline & \multicolumn{2}{|c|}{$\begin{array}{l}\text { Dominant } \\
\text { model }\end{array}$} & \multicolumn{2}{|c|}{$\begin{array}{l}\text { Recessive } \\
\text { model }\end{array}$} & \multicolumn{2}{|c|}{$\begin{array}{c}\text { Nonparametric } \\
\text { analysis }\end{array}$} & \multicolumn{2}{|c|}{$\begin{array}{l}\text { Dominant } \\
\text { model }\end{array}$} & \multicolumn{2}{|c|}{$\begin{array}{l}\text { Recessive } \\
\text { model }\end{array}$} & \multicolumn{2}{|c|}{$\begin{array}{c}\text { Nonparametric } \\
\text { analysis }\end{array}$} \\
\hline & lod score & alpha & lod score & alpha & lod score & $p$-value & lod score & alpha & lod score & alpha & lod score & $p$-value \\
\hline D6S296 & 0.23 & 0.23 & 0.84 & 0.27 & 1.25 & 0.09 & 0.10 & 0.15 & 0.80 & 0.24 & 1.36 & 0.08 \\
\hline D6S277 & 0.15 & 0.19 & 0.81 & 0.26 & 1.12 & 0.12 & 0.04 & 0.10 & 0.73 & 0.23 & 1.17 & 0.12 \\
\hline D6S470 & 0.20 & 0.24 & 0.61 & 0.25 & 1.23 & 0.10 & 0.04 & 0.10 & 0.30 & 0.16 & 1.10 & 0.13 \\
\hline D6S289 & 0.07 & 0.15 & -0.00 & 0.00 & 0.49 & 0.30 & 0.00 & 0.04 & -0.00 & 0.00 & 0.38 & 0.35 \\
\hline D6S260 & 0.17 & 0.24 & -0.00 & 0.00 & 0.76 & 0.21 & 0.03 & 0.10 & -0.00 & 0.00 & 0.63 & 0.26 \\
\hline D6S274 & 0.40 & 0.36 & -0.00 & 0.00 & 1.26 & 0.09 & 0.11 & 0.18 & -0.00 & 0.00 & 1.14 & 0.12 \\
\hline D6S285 & 0.51 & 0.40 & -0.00 & 0.00 & 1.25 & 0.09 & 0.23 & 0.25 & -0.00 & 0.00 & 1.14 & 0.12 \\
\hline D6S461 & 0.21 & 0.26 & 0.00 & 0.04 & 0.47 & 0.31 & 0.40 & 0.35 & -0.00 & 0.00 & 0.38 & 0.35 \\
\hline D6S291 & 0.44 & 0.35 & 0.00 & 0.10 & 0.74 & 0.22 & 0.78 & 0.41 & -0.00 & 0.01 & 0.76 & 0.22 \\
\hline
\end{tabular}

\section{REFERENCES}

American Psychiatric Association. 1994. Diagnostic and Statistical Manual of Mental Disorders, 4th ed. Washington, DC: American Psychiatric Press.

Antonarakis SE, Blouin JL, Pulver AE, Wolyniec P, Lasseter VK, Nestadt G, Kasch L, Babb R, Kazazian HH, Dombroski B, Kimberland M, Ott J, Housman D, Karayiorgou M, MacLean CJ. 1995. Schizophrenia susceptibility and chromosome 6p24-22. Nature Genet 11:235-236.

Cloninger CR. 1988. Schizophrenic disorders: Genetic etiologic factors. In Kaplan H, Sadock B, editors. Comprehensive textbook of psychiatry, vol. 5. Baltimore: Williams \& Wilkins. p 732-744.

Cottingham Jr RW, Idury RM, Schaffer AA. 1993. Faster sequential genetic linkage computations. Am J Hum Genet 53:252-263.

d'Amato T, Campion D, Gorwood PH, Jay M et al. 1992. Evidence for a pseudoautosomal locus for schizophrenia II: replication of a nonrandom segregation alleles at the DXYS14 locus. Br J Psychiatry 161: $59-62$

Daniels JK, Spurlock G, Williams NM, Gardno AG, Jones LA, Murphy KC, Asherson P, Holmans, Fenton I, McGuffin P, Owen MJ. 1997. Linkage study of chromosome $6 \mathrm{p}$ in sib-pairs with schizophrenia. Am J Med Genet 74:319-323.

Dib C, Faure S, Fizames C, Samson D, Drouot N, Vignal DA, Millasseau P Mare S, Hazan J, Seboun E, Lathrop M, Gyapay G, Morissette J, Weissenbach J. 1996. A comprehensive genetic map of the human genome based on 5.264 microsatellites. Nature 380:152-154.

Faraone SV, Matise T, Svrakic DM, Pepple J, Malaspina D, Suarez BK, Hampe CL, Zambuto CT, Schmitt K, Meyer J, Markel P, Lee H, Har kavy-Friedman J, Kaufmann C, Cloninger CR, Tsuang MT. 1998. A genome scan of the European-American schizophrenia pedigrees of the NIMH Genetics Initiative. Am J Med Genet 81:290-295.

Garner C, Kelly M, Lon C, Joselyn G, Carey A, Le Duc C et al.. 1996. Linkage analyses of schizophrenia to chromosome 6P24-P22: an attempt to replicate. Am J Med Genet 67:595-610.

Gottesman II, Shields J. 1982. Schizophrenia, the epigenetic puzzle. Cambridge MA: Cambridge University Press.

Gurling H, Kalsi G, Chen AHS, Green M, Butler R, Read T, Murphy P, Curtis D, Sharma T, Petursson H, Brynjolfsson J. 1995. Schizophrenia susceptibility and chromosome 6p24-22. Nature Genet 11 234-235.

Hwu HG, Yang SY. 1987. Psychiatrist diagnostic assessment: establishment and inter-rater reliability. Chin Psychiatry 2:267-278.

Hwu HG. 1991. Psychiatric diagnostic assessment. In: Hwu HG, editor. Manual of psychiatric diagnosis. Taipei: Publication Committee, College of Medicine, National Taiwan University. p 7-42.

Kendler KS, Diehl SR. 1993. The genetics of schizophrenia: a current, genetic-epidemiologic perspective. Schizophr Bull 19:261-285.

Kendler KS, et al. 1996. Evidence for a schizophrenia vulnerability locus on chromosome $8 p$ in the Irish study of high-density schizophrenia families. Am J Psychiatry 153:1534-1540.

Kaufmann CA, Suarez BK, Malaspina D, Pepple J, Svrakic DM, Markel PD, Meyer J, Zambuto CT, Schmit K, Wynne TC, Harkavy-Friedman J, Hampe CL, Lee Hang, Shore D, Wynne D, Faraone SV, Tsuang MT, Cloninger CR. 1998. NIMH Genetics Initiative Millennium Schizophrenia Consortium: linkage analysis of African-American pedigrees. Am J Med Genet 81:282-289.
Kruglyak L, Daly MJ, Reeve-Daly MR, Lander ES. 1996. Parametric and non-parametric analysis: a unified multipoint approach. Am J Hum Genet 58:1347-1363.

Lahiri DK, Bye S, Nurnberger Jr. JI, Hodes ME, Crisp M. 1992. A nonorganic and non-enzymatic extraction method gives higher yields of genomic DNA from whole-blood samples than do nine other methods tested. J Biochem Biophys Meth 25:193-205.

Lathrop GM, Lalouel JM, Julier C, Ott J. 1984. Strategies for multilocus linkage analysis in human. Proc Nat Acad Sci USA 81:3443-3446.

Levinson DF, Mahtani MM, Nancarrow DJ, Brown DM, Kruglyak L, Kirby A, Hayward NK, Crowe RR, Andreasen NC, Black DW, Silverman JM, Endicott J, Sharpe L, Mohs RC, Siever LJ, Walters MK, Lennon DP, Jones HL, Nertney DA, Daly MJ, Gladis M, Mowry BJ. 1998. Genome scan of schizophrenia. Am J Psychiatry 155:741-750.

Maziade M, Bissonnette L, Rouillard E, Roy MA, Merette C. 1997. Further evidence of a susceptibility gene for schizophrenia in 6P22-6P24: a contribution from the Eastern Quebec population. Am J Med Genet 74:666-667.

Moises HW, Yang L, Kristbjarmarson H, Wiese C, Byerley W, Macciardi F, Arolt V, Blackwood D, Liu X, Sjogren B, Aschauer HN, Hwu HG, Jang K, Livesley WJ, Kennedy JL, Zoega T, Ivarsson O, Bui MT, Yu MH, Havsteen B, Commenges D, Weissenbach J, Schwinger E, Gottesman II, Pakstis AJ, Wetterberg L, Kidd KK, Helgason T. 1995. An international two-stage genome-wide search for schizophrenia susceptibility genes. Nature Genet 11:321-324.

Mowry BJ, Nancarrow DJ, Lennon DP, Sandkuijl LA, Crowe RR, Silverman JM, Mohs RC, Siever LJ, Endicott J, Sharpe L, Walters MK, Hayward NK, Levinson DF. 1995. Schizophrenia susceptibility and chromosome 6p24-22. Nature Genet 11:233-234.

Pulver AE, Karayiorgou M, Wolyniec PS, Lasseter VK, Kasch L, Nestadt G, Antonarakis S, Housman D, Kazazian HH, Meyers D, Ott J, Lamacz M, Liang KY, Hanfelt J, Ullrich G, DeMarchi N, Ramu E, McHugh PR, Adler L, Thomas M, Carpenter WT, Manschreck T, Gordon C.T, Kimberland M, Babb R, Puck J, and Childs B. 1994. Sequential strategy to identify a susceptibility gene for schizophrenia: report of a potential linkage on schizophrenia on chromosome 22q12-q13.1: part 1. Am J Med Genet 54:36-43.

Riley BP, Rajagopalan S, Mogudi-Carter M, Jenkins T, Williamson R. 1996. No evidence for linkage of chromosome 6P markers to schizophrenia in Southern African Bantu-speaking families. Psychiat Genet $6: 41-49$.

Risch N, Baron M. 1984. Segregation analysis of schizophrenia and related disorders. Am J Hum Genet 36:1039-1059.

Saiki RK, Scharf S, Faloona F, Mullis KB, Horn GT, Erlich HA, Amheim N. 1985. Enzymatic amplification of beta-globin genomic sequences and restriction site analysis for diagnosis of sickle cell anemia. Science 230:1350-1354.

Schizophrenia Linkage Collaborative Group (Schizophrenia Linkage Collaborative Group for Chromosome 3, 6 and 8). 1996. Additional support for schizophrenia linkage on chromosome 6 and 8: a multicenter study. Am J Med Genet 67:580-594.

Schwab SG, Albus M, Hallmayer J, Honig S, Borrmann M, Lichtermann D, Ebstein RP, Ackenheil M, Lerer B, Risch N, Maier W, Wildenauer DB. 1995. Evaluation of a susceptibility gene for schizophrenia on chromo- 
some $6 \mathrm{p}$ by multipoint affected sib-pair linkage analysis. Nature Genet 11:325-327.

Straub RE, MacLean CJ, O’Neill FA, Burke J, Murphy B, Duke F, Shinkwin R, Webb BT, Zhang J, Walsh D, Kendler KS. 1995. A potential vulnerability locus for schizophrenia on chromosome 6p24-22: Evidence for genetic heterogeneity. Nature Genet 11:287-293.

Tsuang MT, Bucher KD, Fleming JA. 1982. Testing the monogenetic theory of schizophrenia: an application of segregation analysis to blind family data. Br J Psychiatry 140:595-599.
Turecki G, Rouleau GA, Joober R, Mari J, Morgan K. 1997. Schizophrenia and chromosome 6p. Am J Med Genet (Neuropsychiatric Genet) 74: 195-198.

Vallada HP, Gill M, Sham P, Lim LCC et al. 1995. Linkage studies on chromosome 22 in familial schizophrenia. Am J Med Genet 60:139-146.

Wang S, Sun CE, Waleczak CA, Ziegle JS, Kipps BR, Golden LR, Diehl SR. 1995. Evidence for a susceptibility locus for schizophrenia on chromosome 6pter-p22. Nature Genet 10:41-46. 